\title{
Analysis of failure in landfill construction elements
}

\author{
Eugeniusz Koda ${ }^{1, *}$, Matgorzata Grzyb $^{1}$, Piotr Osiński ${ }^{1}$ and Magdalena D. Vaverková ${ }^{1,2}$ \\ ${ }^{1}$ Faculty of Civil and Environmental Engineering, Warsaw University of Life Sciences, \\ Nowousrynnowska 159 St, 02-766 Warsaw, Poland \\ ${ }^{2}$ Faculty of AgriSciences, Mendel University in Brno, Zemědělská 1, 61300 Brno, Czech Republic
}

\begin{abstract}
The paper presents issues related to the failure of construction elements on landfills. The study investigates threats deriving from landfills, which are the result of emergency events. It reviews landfill failures of different types, showing how they may affect the natural environment, human health and safety. The research is aimed at identifying the causes of these events and at presenting the schedule of remedial works and methods of removing the effects of failures occurring in a selected landfill. Based on the analysis, the use of the geophysical testing method to identify the origin and extent of the failure has been demonstrated as a method crucial for the design of repair works.
\end{abstract}

\section{Introduction}

Analyses of causes of structure failures and disasters have been performed all around the world since many years. They are carried out by continuous monitoring, sophisticated technical and economic analyses, and the results published in scientific journals presented on a number of scientific conferences and workshops.

The safety of structures depends mainly on legal frameworks and requirements, that needs improvement and form changes [1-3]. They should be aimed at the increase of construction process and exploitation safety. However, even best legal regulations will not eliminate errors caused by human factors. This is why the highest quality standards presented by designers, constructors, administrators and owners are crucial for preventing structure failures and disasters.

Structures with a high risk posed on safety are undoubtedly waste landfills. Municipal solid waste (MSW) landfills are geo-structures whose safety and serviceability are directly related to environmental and public health $[4,5]$. To store wastes and preclude the migration of leachates into the natural environment, engineered MSW landfills are sealed with liner systems, commonly designed accordingly to the "multibarrier" concept [6-8]. However, a potential failure or a disaster in the worst case scenario may lead to financial loss and furthermore may expose the natural environment and health or life of people to a major risk.

The optimal design of MSW landfills is a complex, still unsolved issue [9, 10]. For those reasons, analyses of the construction elements of MSW landfills such as: slopes, liners,

${ }^{*}$ Corresponding author: eugeniusz koda@sggw.pl 
drainage systems, appropriate location, repairs and elimination of failure causes are crucial tasks in structure design [11]. This would certainly help preventing errors during maintenance of sites demanding such strict safety regulations.

\section{Disasters and construction failures}

In Poland, generally two institutes gather statistical data regarding the overall number of failures and disasters of engineering structures; these are: the Building Research Institute (ITB) and the Central Construction Supervision Inspector (Główny Urząd Nadzoru Budowlanego; GUNB), which according to the Construction Law is obliged to compile an inventory of such disasters $[2,12]$. Since 1962, ITB has been conducting a record of construction disasters and since 1989 also a construction threats and failures has been recorded based on the data provided by technical universities, construction engineering experts and data gained from GUNB, PZITB and PIIB. Since 2004, GUNB has been continuously publishing reports on construction disasters that took place in the past year. This gives a good starting point for the analysis of already occurred events. The causes of failures and disasters may be sub-divided into two main categories: caused by accidental and random natural events (wind, flood, snow, rain or thunder storm), gas explosions, vehicle impacts into the structure etc., and caused by any other reason, mainly by human factors.

Data collected by GUNB [12] confirm that the number of construction disasters decreases in time. In $2014,33 \%$ of the accidents were caused by human errors; in 2015 this number decreased to $19 \%$ and in 2016 - to $16 \%$. Figure 1 presents the percentage distribution of the main causes of construction disasters reported up to 2017.

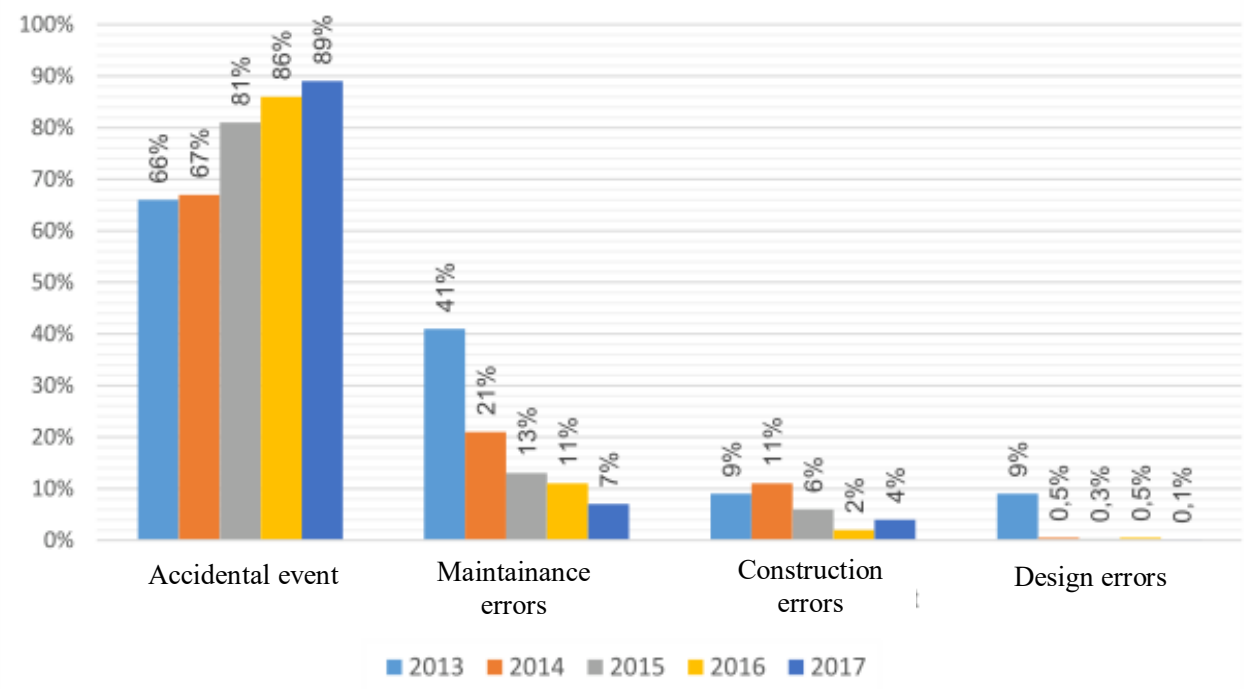

Fig. 1. The main causes of construction disasters in 2013-2017 [12].

Failures and disasters caused by reasons other than natural events may be sub-divided into three groups:

- design errors during preparation of construction documentation,

- construction errors during investment execution or when performing structural works in accomplished buildings,

- exploitation errors made during servicing works.

Table 1 presents the percentage distribution of error groups caused by human factors for construction failures and disasters that took place in 2014-2017. 
Table 1. Percentage distribution of disasters and failures reported in 2014-2017.

\begin{tabular}{|l|c|c|c|c|}
\hline & $\mathbf{2 0 1 4}$ & $\mathbf{2 0 1 5}$ & $\mathbf{2 0 1 6}$ & $\mathbf{2 0 1 7}$ \\
\hline Design errors & $0.5 \%$ & $0.3 \%$ & $0.5 \%$ & $0.1 \%$ \\
\hline Construction errors & $11 \%$ & $6 \%$ & $2 \%$ & $4 \%$ \\
\hline Exploitation errors & $21 \%$ & $13 \%$ & $11 \%$ & $7 \%$ \\
\hline
\end{tabular}

The table shows that design errors are an insignificant part of the entire record of the events. Thus, it is the exploitation and construction errors that require careful attention. Most failures and disaster events take place mainly because of administrator or manager supervision issues, lack of principal safety knowledge, and overloads being transferred onto the structures $[1,2]$. Such failures are usually caused by:

- poor structural condition of the buildings,

- lack of periodical building safety reports,

- lack of administrators attention when poor technological conditions were reported,

- improper exploitation of the structure [4].

The database of failures and disasters is a valuable source of information on the technical condition and construction material quality used for construction, but more importantly it gives information on the elimination of any future potential failures during the investment process.

\section{Failures of landfill structural elements as hazards posed on the natural environment, human health and safety}

Depending on the waste type disposed, landfills may be sub-divided into two major groups: municipal waste and hazardous waste landfills. Usually both landfill types feature a common category of designing solutions and protection systems used:

- excavation bottom and slope liners,

- leachate collection systems and drainage,

- filtration and protection layers,

- degassing systems (if required),

- protective cappings (part of reclamation works),

- $\quad$ solid waste landfills - waste layers compacted mechanically,

- $\quad$ wet (liquid) landfills - waste pulp transported by pipelines.

The disposal technology of wet waste, mainly electro-heating waste combustion plants, requires a different design approach. The crucial construction part is designing dykes and levees, and collecting systems of runoff water infiltrating the landfill body. The scheme of a fully equipped solid waste landfill is presented in Figure 2.

It is common known that a crucial element of every engineering structure investment process is the design and construction stage. Bearing in mind the economic factor, appropriate exploitation and operation of the structure depends on design quality. Another critical element is the construction stage with application of appropriate resources and materials. In the case of landfills, the material used for base insulation and drainage systems needs to have the highest resistance to severe working conditions. It needs to assure full protection conditions, even 30 years after its exploitation. The exploitation stage is one for which any failure may cause major threats to the environment and human safety [14-16]. During this stage the largest number of failures is most probable to occur, including: 


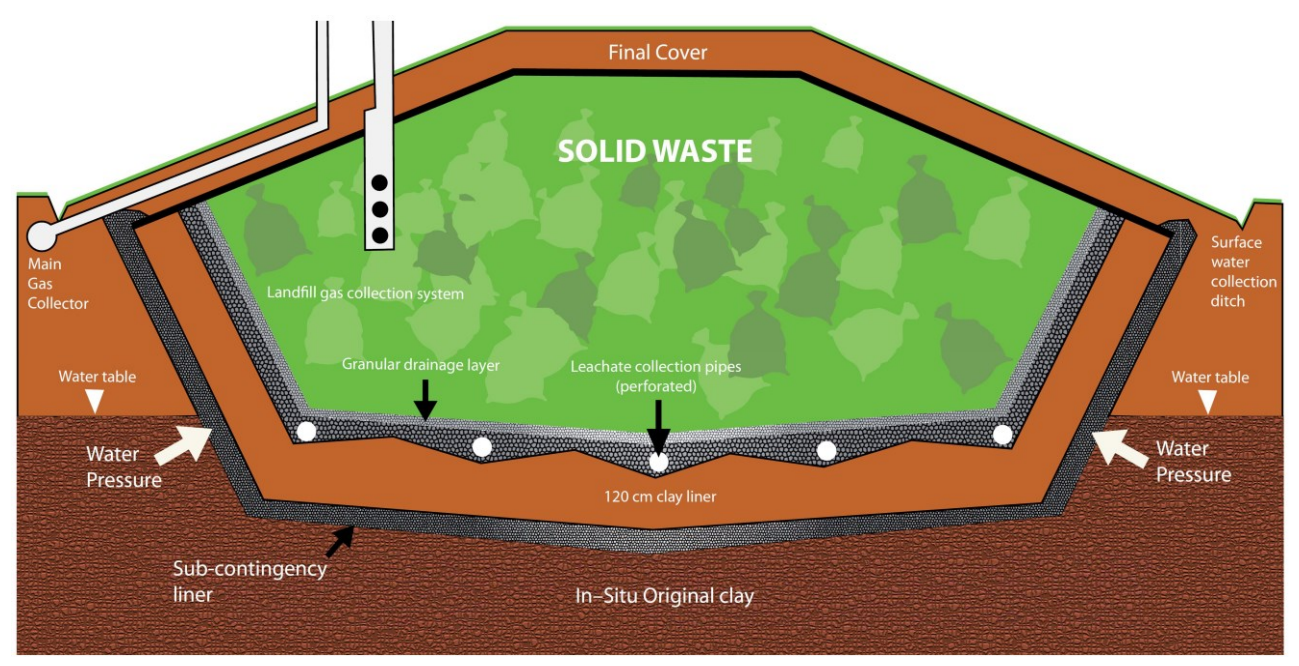

Fig. 2. Solid waste landfill design scheme [13].

- local or overall slope stability or landfill body failures,

- local instability of liners, capping or reclamation layers,

- slope erosion mechanisms,

- leakage of bottom liners,

- leakage of leachate collecting systems,

- damages of associated landfill infrastructure.

In case of any of these failures, there is a serious threat of surface and groundwater pollution, caused by the leachate infiltrating the subsoil. Landfill leachate is a complex mixture characterized by high toxicity, able to contaminate soils and waters surrounding the landfill $[17,18]$ or penetrate deeper soil layers reaching drinking water source zones $[14,15,19]$. Once the leachate releases into the soil, it will interact physically and chemically with both the adjacent groundwater and the soil matrix [20]. However, soil contamination is usually observed only in the immediate area of the landfill. The soil environment comprises a very special place in the biosphere, as it is not a renewable natural resource $[14,15,19]$. Landfill exploitation failures may cause severe chemical soil degradation, which often becomes a permanent issue influencing the growth conditions for plants and microorganisms. One of the most hazardous failures on a landfill, which could turn into a construction disaster, is the slope stability failure of the landfill body or embankments (dams in the case of wet landfills). The major cause of such failures is usually an exploitation error, or poor geological and geotechnical investigation of the subsoil conditions.

\section{Examples of failures in landfill structural elements}

The first example is the Radiowo landfill, located to the north-west of the Warsaw city limits, with an area of 16 ha. In 1962-1991, municipal mixed waste was deposited at the site, and since $1992 \mathrm{ca} .300 \mathrm{t} /$ day of composting ballast waste has been dumped. Because of the height of the landfill, i.e. $60 \mathrm{~m}$, and the inclination of the steep slopes, a major challenge here was to retain the structure stability. In the 1980-ties minor failures were observed on the western slope of the landfill, and in 1991 a significant waste slide of $6000 \mathrm{~m}^{3}$ was recorded on the eastern slope of the landfill [14]. A number of significant cracking occurred on some parts of the structures suggesting deterioration of equilibrium conditions close to its boundary. Because of the ownership issues in the affected area, slope reinforcement works had been delayed, which led to another slope failure in 1995, on the eastern side of the landfill. Due to 
degradation of the nearby forest area, approval of the development plan change was obtained from the Ministry of Environmental Protection, so that the reclamation works could start. Within the range of remedial works, the construction of a load embankment was started in 1997 [19]. It was composed of ballast waste, debris and soil using construction approaches identical as for the western slope that was reinforced earlier. The load embankment construction allowed for improving geotechnical and exploitation safety of the engineering works on the landfill slopes.

Another example is the wet landfill of Skawina Plant ashes, located near the LacznaSkawina sailing waterway. Embankments of a height at $5.6 \mathrm{~m}$ and inclination of 1:1.75 were constructed on clays with interbeddings of peat and river sediments. Lack of a drainage system of the structures resulted in water discharge at the embankments toe. The wastewater level was usually maintained at $1 \mathrm{~m}$ below the crest. In 1964, a $30 \mathrm{~m}$ long breach of the embankment occurred. Vast amounts of soil and ashes reached the sailing waterway and blocked it. The failure cause was most probably lack of drainage systems that led to leakage, which caused liquefaction of the ash zone in the embankment. One day before the failure a heavy rain storm caused rise of the wastewater level in the reservoir, which probably led to hydraulic heave and slope failure [1-3].

The third landfill is located in the Lower Silesian village of Iwiny. A wet landfill of copper mining post-flotation waste was present there. To extend the capacity of the reservoir, the dam was reconstructed in a three stage process. Eventually, the volume of the reservoir reached $16.4 \mathrm{mln} \mathrm{m}^{3}$ and the dam attained a length of $610 \mathrm{~m}$. A disaster took place on December 13th 1967. The dam was breached, and the width of the sinkhole was $68 \mathrm{~m}$ at the bottom to $134 \mathrm{~m}$ at the top of the embankment. Around $12 \mathrm{mln} \mathrm{m}^{3}$ of toxic deposits leaked out covering the nearby households, demolishing 120 houses and 400 associated facilities. 18 people died and 570 were injured. The landfill was eventually closed. The cause of the disaster were structural errors made at the design stage by having poorly recognized the geological conditions of the landfill subsoil. The investigations were conducted only to Quaternary deposits, not reaching deeper soil layers, which led to an erroneous location of the dam axes [3].

The last example of a landfill that caused the most severe environmental impact is located in Ajka in western Hungary. As a result of damage in a metallurgical plant waste reservoir, the most severe ecological disaster in Europe took place in 2010. The reservoir contained chemical waste, being a by-product of the aluminum production process. It comprised iron and titan oxides, and silicon elements. As a result of the reservoir dam breach, ca. 700000 $\mathrm{m}^{3}$ of toxic waste contaminated the nearby villages and rivers, causing the death of 10 people and injury of 150 . The disaster has its impact till present. The toxic red mud contaminated the lands so badly that no longer any biological life is observed there. Elements of the slurry are non-degradable and allow the accumulation in leaving organisms, thus the disaster impact may be observed even in the next long years. Until now there was no clear cause for the reservoir dam breach. Most probably, it was the exceeded amount of deposits stored in the reservoir, construction errors or poor landfill maintenance [1].

\section{A selected landfill as an example of construction failure}

\subsection{Landfill description and history}

The investigated municipal solid waste landfill consists of two separate dumping zones, which will become a single waste embankment in the future. The first zone was constructed in 2002 and operated in 2002-2013. In 2012 and 2013 the second dumping zone was constructed to exceed the period of landfill exploitation till present. Both landfill zones were 
designed and constructed on the boundary with another closed-down municipal landfill and associated facilities operating in 1962-2002. To the north, south and east it bounds with green and forest areas. Figure 3 presents the location and scheme of the landfill on the day before the first dumping zone exploitation date.

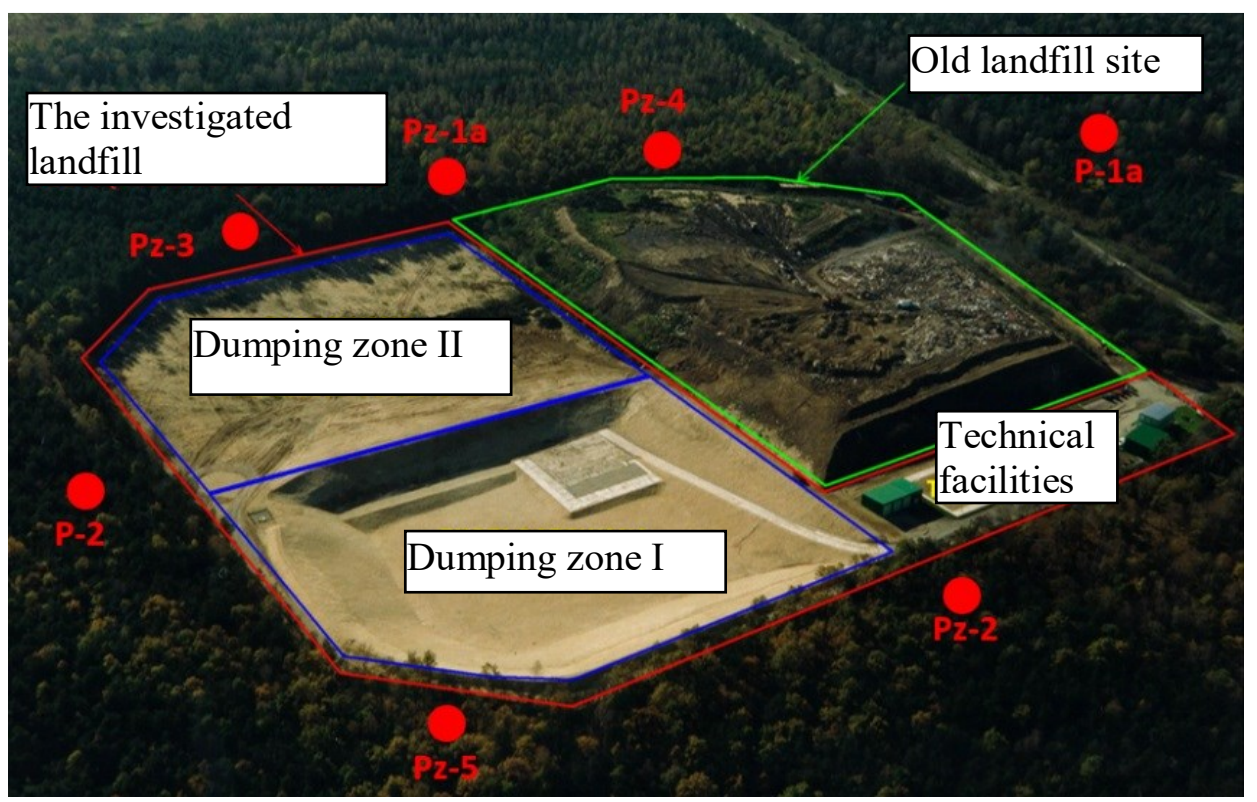

Fig. 3. Location and scheme of the landfill on the day before the first zone exploitation date.

The landfill is an excavation-embankment type. The depth of the excavation is $10 \mathrm{~m}$, and the height reaches $20 \mathrm{~m}$ above the ground. The bottom is sealed with geocomposites and a 2 $\mathrm{mm}$ thick HDPE geomembrane. Over the liners there is a layer of $400 \mathrm{~g} / \mathrm{m}^{2}$ geotextile, a protecting layer of $0.5 \mathrm{~m}$ and a leachate drainage (HDPE pipes of $155 \mathrm{~mm}$ in diameter in gravel and the geotextile cover).The leachate collecting system of the second zone was connected to the system originally constructed for the first dumping zone. The junction point of the two systems is the well S1, which assures the gravitational flow of the leachate to a pumping system. The S1 well was located on the boundary of the two zones and covered after the closure of the first zone, thus access to it was not possible. The leachate is later pumped through a well to the leachate reservoirs, from where the vehicles transport it to a sewage treatment plant. The working capacity of the reservoirs is $2 \times 25 \mathrm{~m}^{3}$.

There were two major failures observed on the landfill site. Both of them concerned structural and technological elements of the first zone and occurred before the excavation of the second zone. The analyzed failures were of a different type and investigated using different approaches.

\subsection{Emergency events at the landfill and their impact on the surroundings}

The first failure on the landfill occurred a short time after the construction of the first dumping zone. It was caused by the filtration layer sliding from the excavation slope liners. The failure did not cause any major issues. The repair included reconstruction of a filtration layer on the slopes. Most probably the cause of failure was usage of material with inappropriate grain size composition and poor weather conditions, such as heavy rain storms. These causes initially caused insignificant rill marks of the filtration layer, which then led to overall failure. The manager of the landfill reported the failure to the constructor, who generally replaced the 
filtration layer. The event did not severely affect the landfill site and did not result in additional repair costs as all the works were covered by the warranty. Figure 4 presents the damages on the excavation slopes.

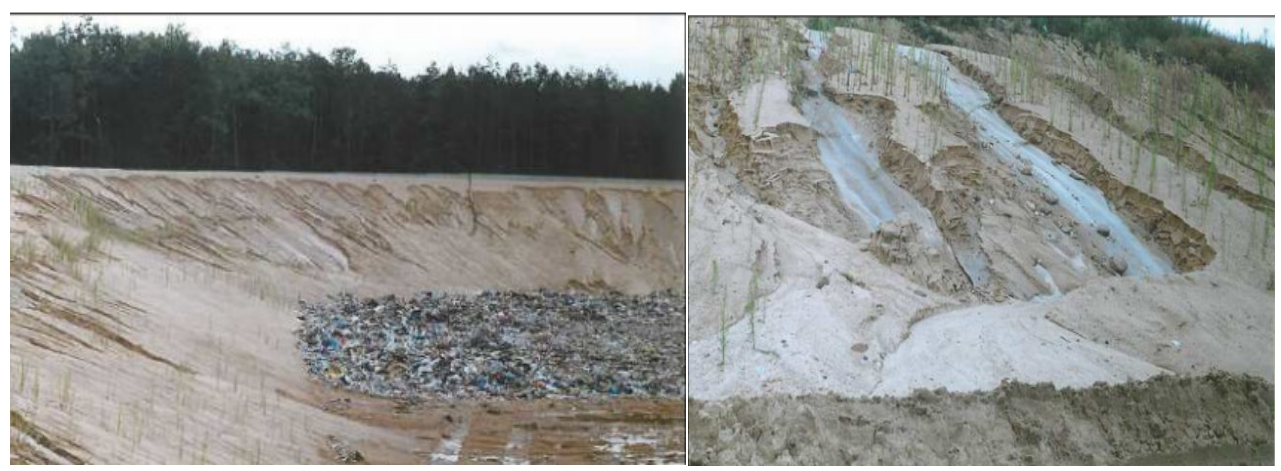

Fig. 4. Damages at the landfill excavation slopes.

The second event was much more complex and much more difficult to investigate. The effect of the failure was noticed only after analysis of data from monitoring systems performed in 2007. Based on piezometric sampling analyses it was established that from 2005 to the middle of 2007, a simultaneous increase of electric conductivity (EC) and total organic carbon (TOC) was traced in piezometer P-2. The investigated piezometer was located on the south-eastern side of the first zone, which is the pathway of groundwater discharge from the landfill subsoil. Results of physical and chemical contamination indicators of groundwater samples from piezometer P-2 are presented in Table 2. According to legal regulations for groundwater class $\mathrm{V}$, the limit value for $\mathrm{EC}$ is $>3000 \mu \mathrm{S} / \mathrm{cm}$ and for TOC is $>20 \mathrm{mgC} / \mathrm{dm}^{3}$.

Another issue was that during the site investigation, a failure of one of the leachate transferring pumps was reported. This meant that poor quality of the samples tested were caused by leachate overflowing the boundary embankment located between the two dumping zones, especially during severe weather conditions.

The results revealed that the acceptable concentration values are exceeded by as much as five times for EC and 50 times for TOC, for the III water class requirements. Bearing in mind that in the closest vicinity there is an old, closed MSW landfill, the first conclusion deriving from such low groundwater quality standards was the a liner ruptured liner was ruptured at some stage, and the leachate is infiltrating the subsoil.

Another issue occurred when it was decided to verify the condition of liners by removing part of the drainage layer. 
Table 2. Results of analysis of groundwater samples contaminated with EC and TOC, collected from piezometer P-2.

\begin{tabular}{|c|c|c|c||}
\hline Sampling date & $\begin{array}{c}\text { Groundwater level } \\
{[\mathrm{m} \text { b.s.1.] }}\end{array}$ & $\begin{array}{c}\mathrm{EC} \\
{[\mu \mathrm{S} / \mathrm{cm}]}\end{array}$ & $\begin{array}{c}\text { TOC } \\
{\left[\mathrm{mg} / \mathrm{dm}^{3}\right]}\end{array}$ \\
\hline \hline 18.06 .2004 & 17.2 & 230 & 9.47 \\
\hline 13.09 .2004 & 17.6 & 800 & 2.75 \\
\hline 06.12 .2004 & 17.1 & 567 & 13.64 \\
\hline 30.03 .2005 & 17.0 & 274 & 48.87 \\
\hline 22.06 .2005 & 17.2 & 1664 & 150.00 \\
\hline 02.09 .2005 & 17.3 & 4430 & 337.60 \\
\hline 23.12 .2005 & 17.4 & 8070 & 166.70 \\
\hline 02.03 .2006 & 17.3 & 5650 & 417.00 \\
\hline 29.06 .2006 & 17.7 & 8460 & 287.00 \\
\hline 28.09 .2006 & 17.7 & 8055 & 62.90 \\
\hline 09.12 .2006 & 17.0 & 10910 & 280.00 \\
\hline 23.02 .2007 & 17.0 & 11120 & 511.00 \\
\hline 15.05 .2007 & 17.1 & 11469 & \\
\hline
\end{tabular}

It was noticed that the geomembrane was damaged. Ruptures in the geomembrane are presented in Figure 5, with associated repair works to seal the liner.
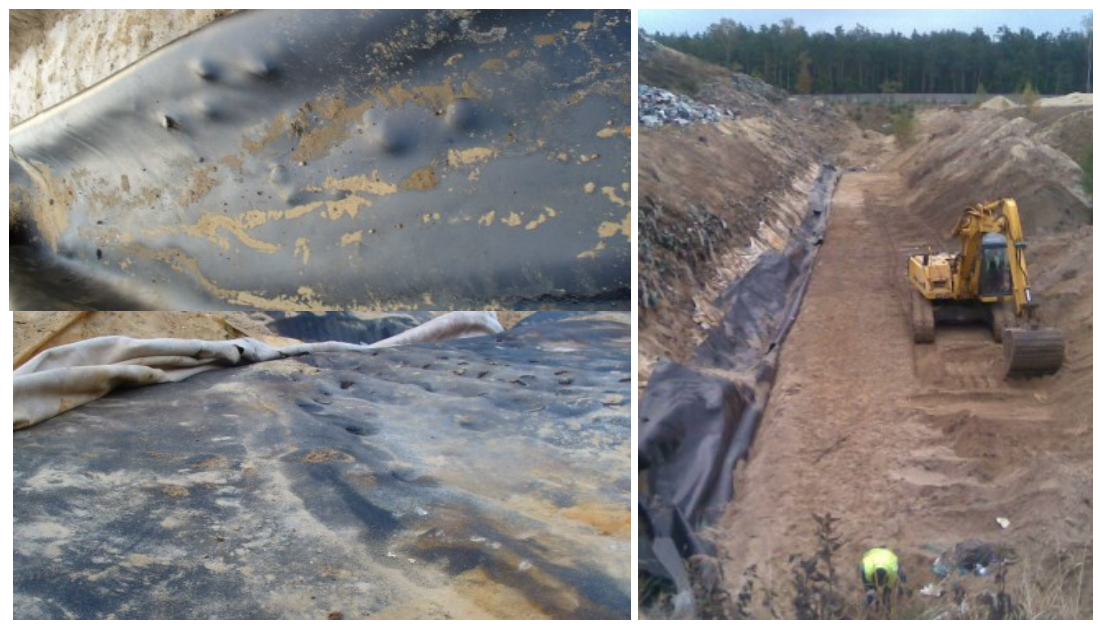

Fig. 5. Damages on the excavation slopes.

According to the reported damages and failures the following repairs were scheduled:

- replacement of the leachate pumping system, introduction of automatic systems for pumping operations,

- $\quad$ exposure of the excavation slopes (overlying the insulation on the waste slope)

- build-up of the embankment level

- removal of ruptured geomembrane and replacement with a new one,

- re-layering of liners on the embankment in between the two dumping zones,

- placing of an additional drainage pipeline to improve leachate collection capability.

The technical scheme of the repair works is presented in Figure 6. 


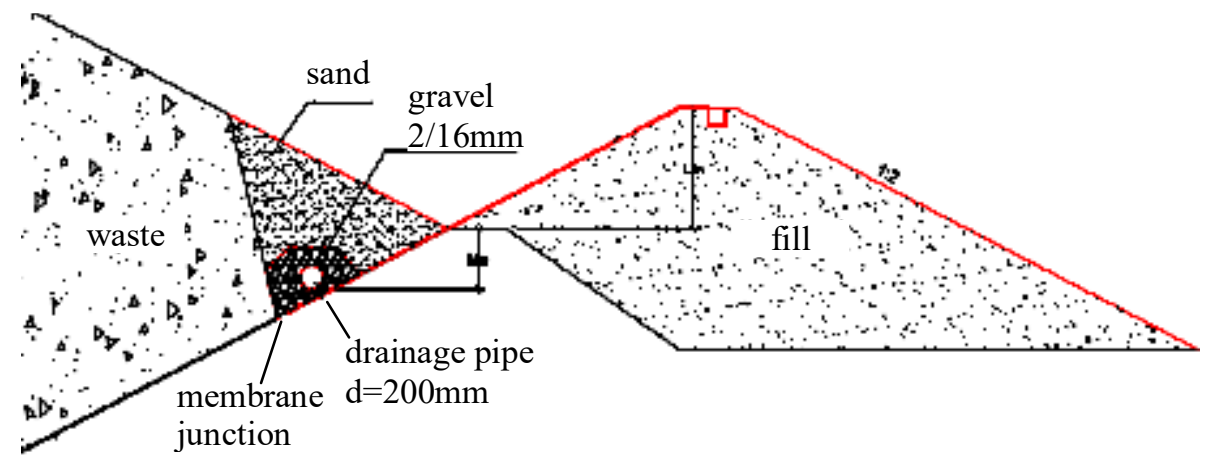

Fig. 6. Technical scheme of repair works introduced in the landfill site.

The entire works helped eliminating the embankment leachate overflow and infiltration through a potentially damaged geomembrane. Since mid-2008, based on monitoring results, a significant decrease of EC and TOC concentrations has been reported. Figures 7 and 8 present the concentration of indicators in piezometer P-2 between 2004 to 2018.

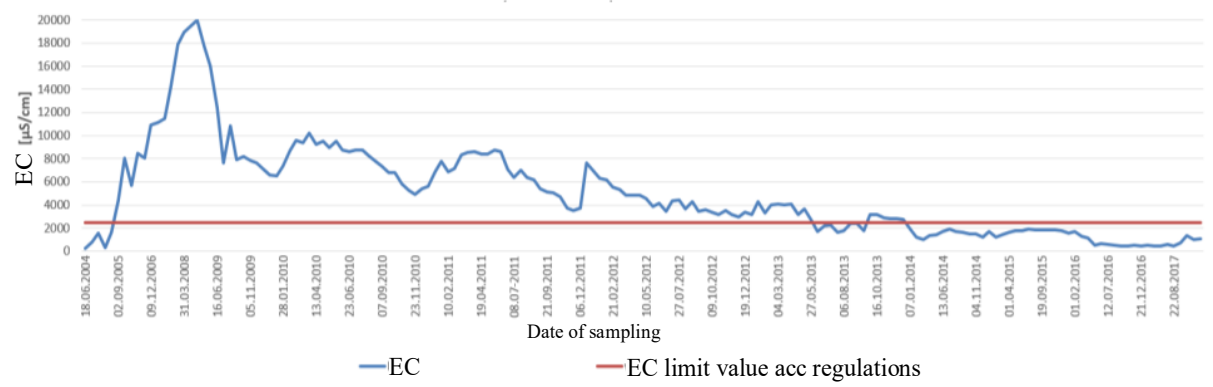

Fig. 7. EC concentration in P-2 in 2004-2017.

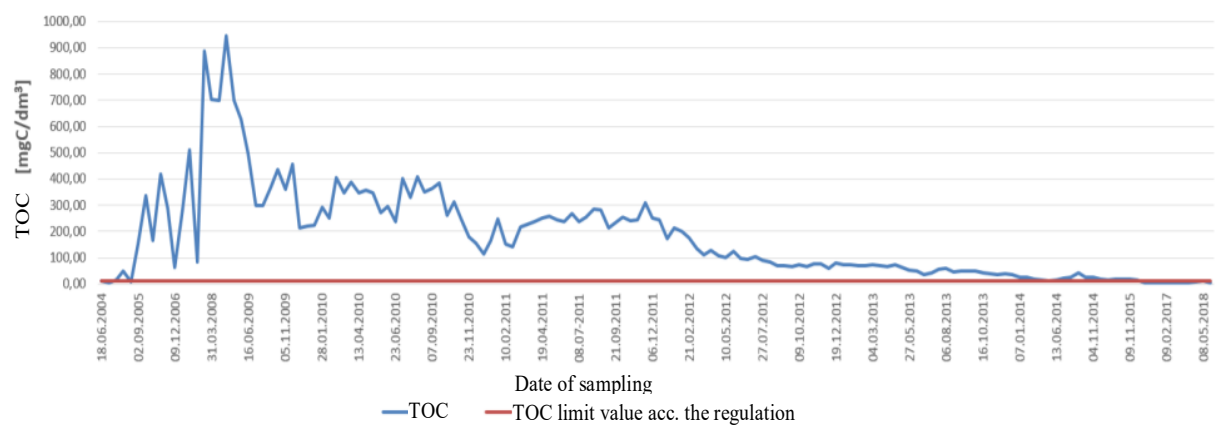

Fig. 8. TOC concentration in P-2 in 2004-2018.

\subsection{Geoelectrical tests used for determination of failure cause}

For the purpose of identifying the contamination causes reported in P-2 and establishing the range and distribution of soil-water environment contamination, the subsoil was investigated using geophysical and sociological survey methods. In practice, the electrical resistivity of soil is measured using a four-electrode configuration. In this method, an electrical current is supplied to the soil using two electrodes (A and B), inducing an electric field, whereas $\mathrm{M}$ and 
$\mathrm{N}$ electrodes measure its potential. The electrical resistivity of the soil can be determined based on the known difference between the electric field potential and the current [21-23]. The resistivity is given by the equation:

$$
\rho=k \frac{\Delta V}{I}
$$

where:

$\rho$ - bedrock resistivity,

$I$ - intensity of current applied to the soil by electrodes $\mathrm{AB}[\mathrm{mA}]$,

$\Delta V$ - differential potential between electrodes $\mathrm{MN}[\mathrm{mV}]$,

$k$ - geometrical coefficient of electrode positioning [m].

The approach behind the method is based on the observation of the electric field properties. The electric field is artificially excited by introducing electrodes to the ground, for which the differential potential is maintained. The method is used to measure resistivity of a bedrock subjected to electrical field excitation, which allows for the precise location of layers with a different electrical resistivity potential. The surface soil layer limits the elliptic shaped lines distributed within the subsoil. The depth of electrical field presence strictly depends on the distribution of electrode distance [21, 22]. The overall idea of the electric resistivity approach is presented in Fig. 9.

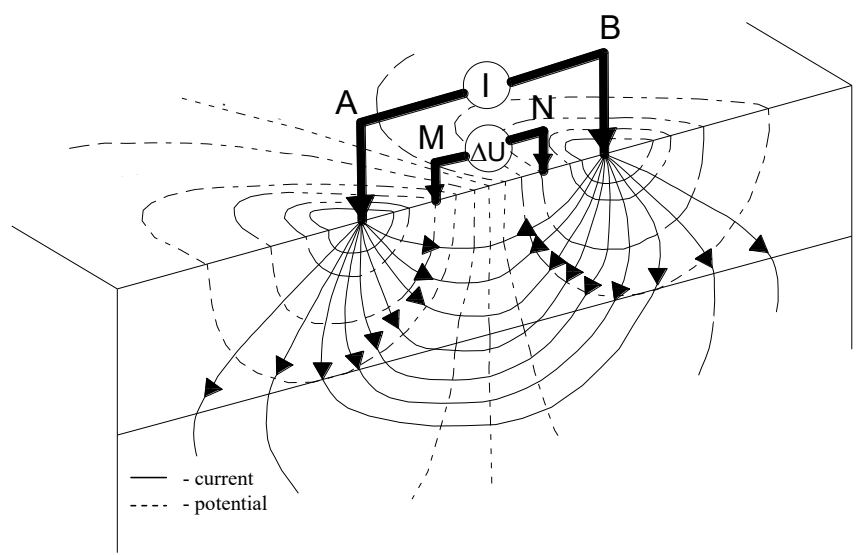

Fig. 9. Electrical resistivity measurement scheme using a four electrodes approach [21].

In this particular study, usage of the geophysical survey was aimed at: locating the low permeable soil layers (clay) building the landfill subsoil, determining the groundwater level depth and its flow paths, and finally establishing the source of exceeded concentration values of EC and TOC in piezometer P-2. The electrode distribution allowed investigating the subsoil down to $35 \mathrm{~m}$. The survey led to the determination of the position of clays at the depth of 12-20 m.

Particular attention was paid to random resistance values of granular soils and clays in the western part of the landfill. The reason for this was the close vicinity of the old landfill and the first exploited dumping zone. Impermeable clay deposits were identified in the front of the dumping zone and the groundwater path flows were determined to be towards piezometer P-2. A collecting well and leachate pumping system was also located along the flow direction. Due to such observations it was clear that the geomembrane rapture was not 
the issue. Further observations showed that the identified geological profile was favorable to the self-purification process of the soil-water environment.

The location of geoeletrical cross-sections, piezometers and groundwater flow directions determined based on the site investigation is presented in Figure 10.

\section{Conclusions}

Based on the investigations and observations, it was assumed that the most probable cause for contamination was failure of the leachate collecting system (well, pipeline, pumping system). Within a range of repairing works, it was recommended to investigate the insulation of those elements and to create a hydraulic barrier collecting the pollutants by pumping it using piezometer P-2 and transfer it to the leachate reservoir. Further investigations confirmed failures of the pumping system.

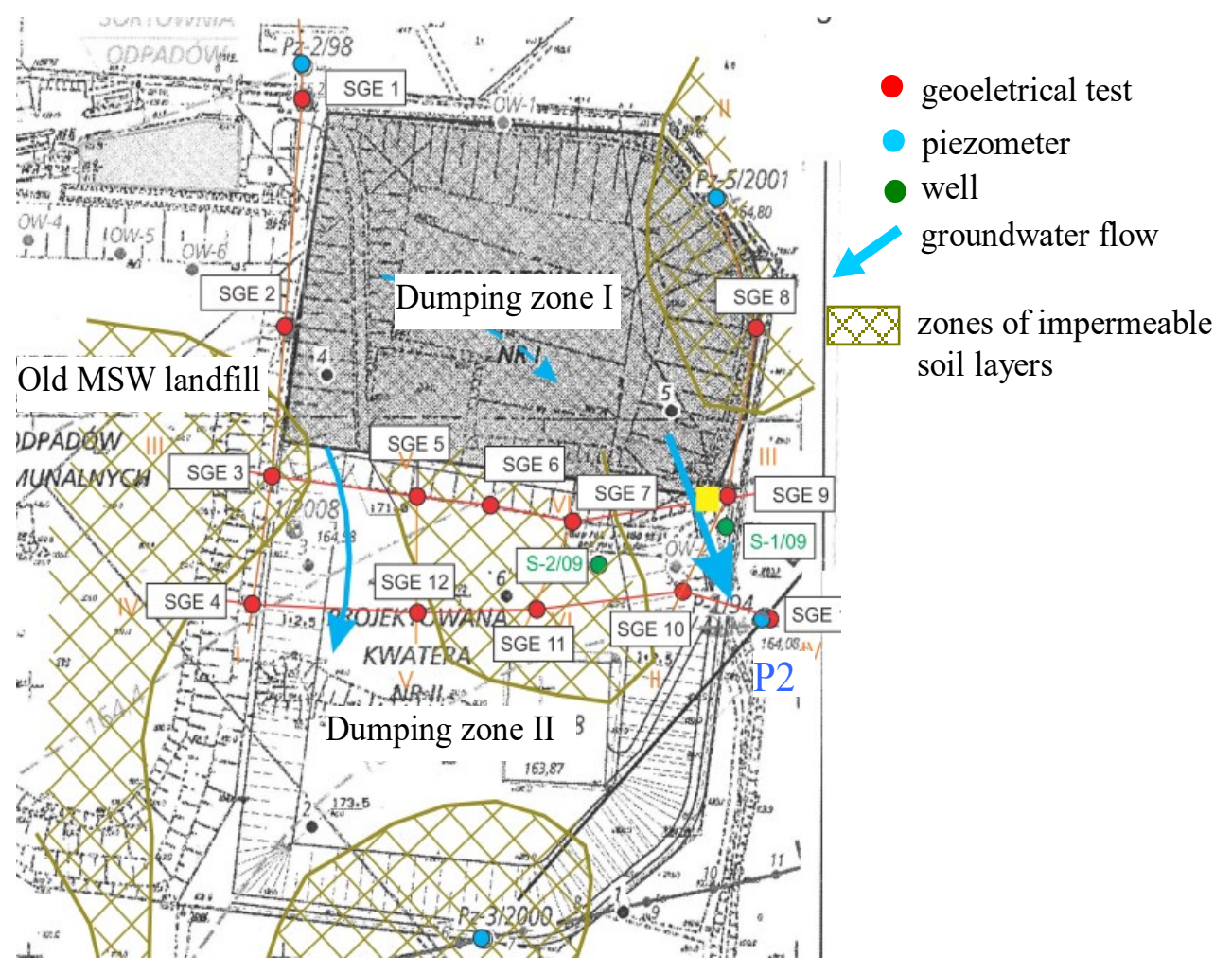

Fig. 10. Map showing the geoelectrical survey with determined zones of impermeable layers and groundwater flow directions.

By analyzing the changes of groundwater test results, the optimum pumping capacity was established, therefore the recommendations could lead to the quality improvement of the soilwater environmental conditions. Eventually, the failure did not affect human health and safety, however the event could get much worse as the contamination plume gradually shifted towards the households. Failures identified at an early stage, establishment of monitoring systems, and performed groundwater quality analyses result in bringing back the initial environmental conditions of the investigated area. 


\section{References}

1. L. Runkiewicz, Przegląd Budowlany, 9, pp. $44-49$ (2008) [in Polish]

2. L. Runkiewicz, Inż Bud. 11 (2011) [in Polish]

3. M. Grzyb. (Master's Thesis, SGGW, Warszawa, 2018) [in Polish]

4. S.J. Feng, J.Y. Chang, H.X. Chen, D.M. Zhang, S. Dyn. and Earth. Eng. 116, pp. 96-106 (2019)

5. H. Brandl, Environmental geotechnical engineering of landfills and contaminated land (Proceedings of The $11^{\text {th }}$ Baltic Sea Geotechnical Conference On Geotechnics In Maritime Engineering, 2, pp. 803-826, 2008)

6. D.A. Rubinos, G. Spagnoli, J. of Env. Manag. 232, pp. 271-285 (2019)

7. M. Manassero, W.F. Van Impe, A. Bouazza, Water disposal and containment (Proceedings of. $2^{\text {nd }}$ International. Congress on Environmental. Geotechnics., 3, pp. 1425-1474, 1996)

8. N. Huvaj-Sarihan, T.D. Stark, Back Analyses of Landfill Slope Failures $\left(6^{\text {th }}\right.$ International Conference on Case Histories in Geotechnical Engineering, 2.34, 2008)

9. M. Cuartas, A. López, F. Pérez, A. Lobo, Waste Manag. 71, pp. 287-300 (2018)

10. G. Blight, Waste Manag. Res. 26(5) (2008)

11. L. Maritsa, P.E. Tsakiridis, N.S. Katsiotis, H. Tsiavos, D. Velissariou, A. Xenidis, M. Beazi-Katsioti, J. of Env. Chem. Eng. 4(2), pp. 1818-1825 (2016)

12. Główny Urząd Nadzoru Budowlanego (2018) [in Polish]

13. M.G. Schneider, Poster presentation (2018)

14. E. Koda, S. Żakowicz, Physical and hydraulics properties of the MSW for water balance of the landfill (Proceedings of the $3^{\text {rd }}$ International Congress on Environmental Geotechnics, 1, pp. 217-222, 1998)

15. M.D. Vaverková, D. Adamcová, Env. Eng. Manag. J. 17(3) (2018)

16. M. Veverkova, M. Radziemska, S. Barton, A. Cerda, E Koda, Land Der. and Dev. (2018)

17. D. Baderna, F. Caloni, E. Benfenati, Env. Int. 122, pp. 21-30 (2019)

18. A. Jahanfar, M. Amirmojahedi, B. Gharabaghi, B. Dubey, E. McBean, D. Kumar, Waste Manag. Res. 35(3) (2017)

19. E. Koda, A. Miszkowska, A. Sieczka and P. Osiński, Env. Geotech. (2018)

20. Q. Tang, F. Gu, Y Zhang, Y Zhang, J. Mo, J. of Env. Manag. 222, pp. 44-53 (2018)

21. E. Koda, A. Tkaczyk, M Lech, P. Osiński, App.Scien. 7(3) (2017)

22. E. Koda, M. Lech, P. Osinski, Wykorzystanie metody elektrooporowej do rozpoznania nieszczelności izolacji składowisk odpadów (Proceedings of XXVII Scientific-Technical Conference on Structural Failures, 2015) [in Polish]

23. E. Koda, P. Osiński, Geotech. Spec. Pub. (2016) 